\title{
Species of the Hoplias aff malabaricus complex (Characiformes: Erythrinidae): An investigation of coexistence in a Neotropical floodplain
}

\author{
Marília Hauser ${ }^{1}$ \& Evanilde Benedito B $^{2,3}$
}

\author{
${ }^{1}$ Laboratório de Ictiologia e Pesca, Universidade Federal de Rondônia. Rodovia BR 364, km 9.5, 78900-000 Porto Velho, RO, \\ Brazil. E-mail: mariliahauser@yahoo.com.br \\ ${ }^{2}$ Departamento de Biologia, Nupélia, Universidade Estadual de Maringá. Avenida Colombo 5790, 87020-900 Maringá, PR, \\ Brazil.E-mail: eva@nupelia.uem.br \\ ${ }^{3}$ Corresponding author.
}

\begin{abstract}
This study assessed the coexistence of three species of thraira present in the Upper Paraná River floodplain, using population structure as an investigation tool. The species were designated as: Hoplias sp. 1, introduced after the construction of the Itaipu reservoir, and Hoplias sp. 2 and Hoplias sp. 3, native species that have been identified as Hoplias aff. malabaricus. We tested the hypothesis that those species in fact differ from each other in respect of population abundance, sex ratio, relative frequency of adults and juveniles, length structure and weight-length relationship. Additionally, possible effects of the flood pulse on the first four of these parameters were investigated. Samples were collected quarterly from March 2006 to December 2007 from nine collection sites on the floodplain. Hoplias sp. 1 presented a greater balance of sex ratio and length structures over the seasons, as well as a higher allometric coefficient. The population attributes of Hoplias sp. 2 and Hoplias sp. 3 showed a high responsiveness to hydrological seasonality, indicating that these species exploit available resources in a conspicuous flood period with greater efficiency. These differences, beyond reflecting possible mechanisms that allow closely related species to coexist, indicate the importance of understanding the life strategies adopted by each species which, as part of a complex system, are considered key elements of the aquatic community structure in the region, providing important information for habitat management and biodiversity conservation.
\end{abstract}

KEY WORDS. Dams; flood pulse; species introduction; structure population; thraira.

Technological advances have increased the demand for electricity in Brazil, and this has been reflected in the construction of new dams, implying the establishment of reservoirs (Souza et al. 2008). These reservoirs transform the structure of the entire aquatic environment, causing important changes in the ichthyofauna not only in the flooded area, but also upstream and downstream of it (Agostinho et al. 2007).

In spite of the superior stretch of the Paraná River, which is located between the Paranapanema River mouth and the Itaipu reservoir and which includes an extensive floodplain and the last dam-free stretch of the Upper Paraná River, this area suffers the effects of both upstream and downstream impoundments. As a consequence of the reservoir cascade located upstream of the Upper Paraná River floodplain, the current flow in this ecosystem has been controlled, including control of the period, frequency and intensity of the flood pulse. These changes were intensified after the construction of the Porto Primavera reservoir (Petry et al. 2003, Agostinho et al. 2004). Although the effects of the impoundment are less pronounced in the upstream region, aquatic fauna in the basins, which are naturally fragmented by large waterfalls, may be mixed by the impoundments there, as occurred in the basin of the Upper Paraná River floodplain after the formation of the Itaipu reservoir (Agostinho et al. 2007). This impoundment inundated the Sete Quedas Falls of the Paraná River, the limit of two hydrographic ecoregions, and moved this natural barrier $150 \mathrm{~km}$ downstream, allowing a remarkable dispersal of species from the Middle Paraná River to superior stretches, including individuals from the Hoplias aff. malabaricus complex (BLOCH 1794), known as thraira (Júlio JúNIOR et al. 2009).

According to some authors (Dergam \& Bertollo 1990, Dergam et al. 1998, Vicari et al. 2005), H. aff. malabaricus exhibits some of the highest known inter- and intrapopulation karyotypic diversities, with seven identified cytotypes in South America which, due to the absence of gene flow, suggests a species complex (Bertollo et al. 2000). Pazza \& Júlio Júnior (2003), studying this complex in the Upper Paraná River, reported the presence of three cytotypes (A, C, D) coexisting in sympatry separated by a large genetic distance, one cytotype (C) being introduced after the formation of the Itaipu Reservoir, and the other two cytotypes (A, D) being native to the region. Graça \& Pavanelli (2007) classified these cytotypes as 
three distinct species based on specific morphological traits and designated them as Hoplias sp. 1, Hoplias sp. 2 and Hoplias sp. 3 (cytotypes $\mathrm{C}, \mathrm{D}$ and $\mathrm{A}$, respectively).

The $H$. aff. malabaricus complex exhibits a wide geographical distribution (Gery 1977, Barbieri et al. 1982, MELlo et al. 2006, Vicari et al. 2006, Gomes et al. 2007) and is commonly found in the biotopes of the Upper Paraná River floodplain (BIALETZKi et al. 2002), where this complex is important among piscivorous fish species with a high contribution to both number and biomass (LuIz et al. 2004).

Petry et al. (2007), analysing the complex as a single species, verified its key role in the Upper Paraná River floodplain in structuring assemblages of fish in isolated lagoons. However, despite the importance of thraira to the dynamics of freshwater ecosystems, the structure of its population is poorly known in the region, being restricted to results obtained from the Itaipu reservoir after its impoundment.

Understanding the population structures of species is one of the greatest objectives of biology, especially for teleost fishes, which present great variability in strategies and practices for survival (Winemiller 1989, Orsi et al. 2004). Odum (1988) reports that population parameters offer components that may be used to determine patterns of strategy and survival of species, as they allow the elucidation and interpretation of several responses to their ecology (VAzzoler \& Amadio 1990).

Thus, considering that most studies of Hoplias aff. malabaricus focus on the complex without distinguishing between the species that it is composed of, our study aimed to determine the population structure of the three species of Hoplias Gill, 1903 present in the Upper Paraná River floodplain. Additionally, due to the fact that the regularity of variation in the hydrometric level may function as a key factor in establishing complex relationships of dependence between the organisms and the floodplains (Poff et al. 1997), we also examined the possible effects of the flood pulse on the population structure of these species. According to BEGon et al. (2007), congener species must at least exhibit different behavioral strategies to coexist. Considering that morphological and reproductive differences have already been identified for these three species of Hoplias, the hypothesis of this study was that these species differ in several population parameters: abundance, sex and adult/juvenile ratio, length structure and weight-length relationship.

\section{MATERIAL AND METHODS}

The Paraná River is the second longest in South America (Agostinho \& Júlio Júnior 1999). Its upper portion, designated the Upper Paraná, is represented by the following hydroelectric dams (HEDs): the Itaipu (downstream) and the Porto Primavera (upstream) (Souza Filho \& Stevaux 2004). The study area consisted of a section of the braided floodplain of the Upper Paraná River $\left(22^{\circ} 40^{\prime} \mathrm{S}\right.$ and $22^{\circ} 50^{\prime} \mathrm{S}$ latitude and between $53^{\circ} 10^{\prime} \mathrm{W}$ and $53^{\circ} 40^{\prime} \mathrm{W}$ longitude), located between the mouths of the
Paranapanema and Ivinheima rivers and representing the last undimmed stretch of the Paraná River in Brazil. Since 1999, this region has been included in the Long-Term Ecological Research Program (LTER) developed by the Universidade Estadual de Maringá (Fig. 1).

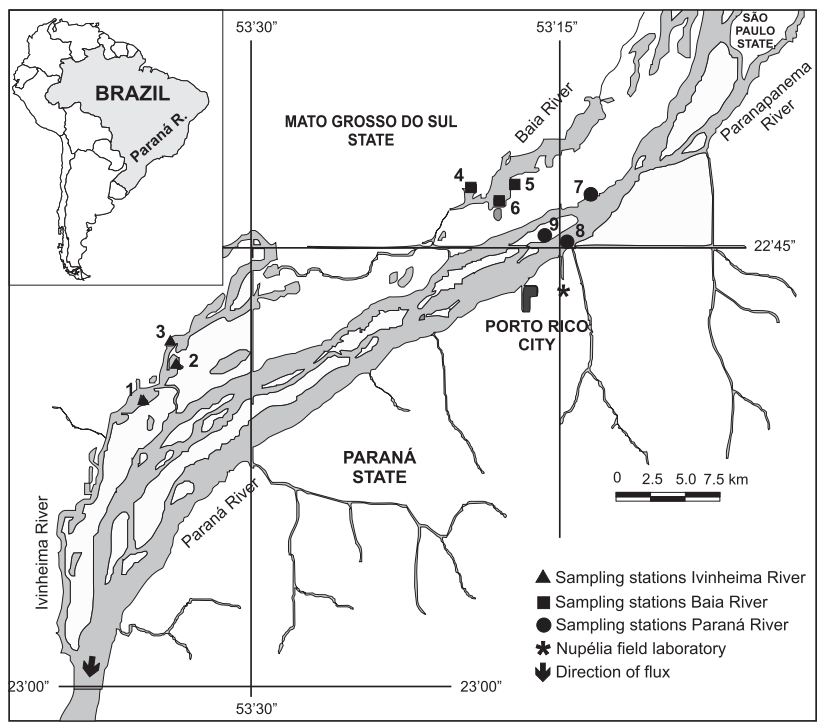

Figure 1. The study area, with the location of the sampling stations in the Upper Paraná River floodplain: PR (1 - Paraná River, 2 - Garças lagoon, 3 - Pau Véio backwater); BA (4 - Baía River, 5 Fechada lagoon, 6 - Guaraná lagoon); IVI (7 - Ivinheima River, 8 Patos lagoon, 9 - Ventura lagoon).

To determine the flood period in the study area, hydrologic data from the Paraná River were obtained from the Fluviometric Station of Porto São José (state of Paraná) and from the Itaipu Binacional. A quota of $3.5 \mathrm{~m}$ was considered the limit for overflow of the Paraná River, and a flood period was designated when the hydrometrical level exceeded this value (Cunico et al. 2002, Thомаz et al. 2004) (Fig. 2).

Species samples were collected quarterly between March 2006 and December 2007 from nine stations belonging to three subsystems: Baía - BA (Baía River, Fechada lagoon and Guaraná lagoon); Paraná - PR (Paraná River, Garças lagoon and Pau Véio backwater); and Ivinheima - IV (Ivinheima River, Ventura lagoon and Patos lagoon) (Fig. 1). Specimens were collected using gill nets ( 2.4 to $16 \mathrm{~cm}$ mesh) with standardized fishing effort exposed for a period of twenty-four hours and verified every eight hours. After sampling, the specimens were anaesthetized and killed as described for fishes in AVMA (2007). The following were also measured for each specimen: standard length $\left(\mathrm{L}_{s}\right)(\mathrm{cm})$, total weight $\left(\mathrm{W}_{\mathrm{t}}\right)(\mathrm{g})$, sex and gonadal maturation stage (immature, rest, maturation, in reproduction, spent; adapted from VAzzoLER 1996). 


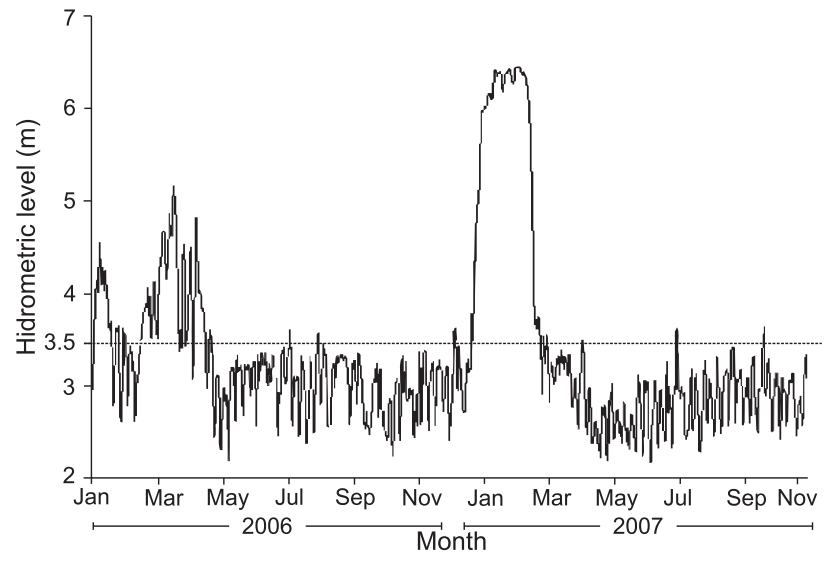

Figure 2. Hydrological regime of the Paraná River measured at Porto São José municipality. Stippled line $=$ water level required for initial inundation of the floodplain (Source: Fluviometric Station's Porto São José-PR).

Individuals were classified according to Graça \& Pavanelli (2007) as Hoplias sp. 1, Hoplias sp. 2 and Hoplias sp. 3, and vouchers were deposited in the ichthyologic collection of the Museum of Nupélia at the Universidade Estadual de Maringá (Hoplias sp. 1 voucher specimen: NUP3456, Hoplias sp. 2: NUP3457, Hoplias sp. 3: NUP3458).

Species abundance was determined using the absolute frequency, i.e., the total number of individuals, considering the standardized sampling effort. Sex ratio was obtained by observing the frequency of males and females and comparing to the expected proportion (1:1), while the proportion of juveniles to adults was analyzed using the relative frequency of these individuals. Specimens with immature gonads were considered to be juveniles, whereas all other stages of gonadal maturity were deemed adults (VAzzoler 1996). For both analyses of proportion, the results were tested whenever possible using a ' $G$ ' test to determine significant differences. The three above-mentioned population attributes were estimated for the three species of Hoplias and analyzed monthly and to standard length class. The amplitude of these classes was established using Sturges' rule (VIEIRA 1991), obtained using the difference between the smallest and largest standard length sampled, for both 2006 and 2007.

Froese (2006) indicates that a reliable length-weight relationship, which allows for evaluation of the ' $b$ ' exponent, requires at least 10 small, medium and large specimens. Thus, considering the low number of individuals of Hoplias sp. 3 collected during the study period, its length-weight relationship was established by pooling individuals of both sexes, whereas for Hoplias sp. 1 and Hoplias sp. 2, this was determined for males and females separately. These relationships were determined using the equation: $\mathrm{W}_{\mathrm{t}}=\mathrm{a} \cdot \mathrm{L}_{\mathrm{s}}^{\mathrm{b}}$, where $\mathrm{W}_{\mathrm{t}}=$ total weight, $\mathrm{L}_{\mathrm{s}}=$ standard length, $a=$ linear coefficient and $b=$ slope coefficient
(Le Cren 1951). The parameters of these relationships were estimated after logarithmic transformation of the values of weight and standard length and subsequent adjustment of a straight line to the points using the least squares method (VAnzolinI 1993).

To test for possible differences between the population parameters using the adjusted curves for males and females, an analysis of covariance (ANCOVA) (GOLDBERg \& SCHEINER 1993) was applied to the coefficients of the linear regressions of standard length and total weight $\left(\log _{10}\right)$. To investigate the development patterns of these fishes, a Student's test was employed on the slope coefficient (b) of species to evaluate the null hypothesis $\left(\mathrm{H}_{0}\right)$ : $\mathrm{b}=3$, using the equation: \%b-3\%/standard error of the ' $b$ ' (ZAR 1996).

The significance level adopted for all statistical analyses was $5 \%$, and the parameters from the length-weight relationship and ANCOVA were determined using Statistica ${ }^{\mathrm{TM}}$ software for Windows 7.1. (STATSOFt 1996).

\section{RESULTS}

During the two annual cycles, we captured and evaluated 434 individuals of Hoplias sp. 1 (221 females and 213 males), 604 individuals of Hoplias sp. 2 (280 females and 324 males) and 15 individuals of Hoplias sp. 3 (7 females and 8 males). In 2006, Hoplias sp. 1 and Hoplias sp. 2 exhibited similar absolute frequencies, with a small predominance of the first species between September and December. In 2007, Hoplias sp. 2 was more abundant between June and December, especially in June, when it presented more than twice the number of individuals found for Hoplias sp. 1. Hoplias sp. 3 was found to have the lowest frequency, with a higher occurrence in March and September 2007 (Fig. 3).

In 2006 , more than $80 \%$ of individuals of Hoplias sp. 1 and Hoplias sp. 2 ranged from 19 to $26 \mathrm{~cm}$ standard length, with similar absolute frequencies of these two species (Fig. 3). In 2007, there was a verified increase in the number of individuals for all three species, especially Hoplias sp. 2, which were widely distributed among the standard length classes (Fig. 3).

For annual sex ratio only, Hoplias sp. 2 and Hoplias sp. 3 exhibited a significant difference in 2006, when the males were more frequent $(\mathrm{p}<0.05)$ (Tab. I). Hoplias sp. 1 did not exhibit significant differences in the monthly sex ratio, whereas Hoplias sp. 2 showed significant predominance of males in March $(G=$ 5.01) and June $(\mathrm{G}=4.97)$ of 2006 and in December of 2007 ( $\mathrm{G}=$ 4.35) (Fig. 4). For both species, significantly more adults were collected than juveniles during the entire period ( $\mathrm{p}>0.05)$, except in March 2007 ( $\mathrm{G}=0.51$ for Hoplias sp. 1 and $\mathrm{G}=0.34$ for Hoplias sp. 2). However, we recorded an increase in juveniles in 2007, especially for Hoplias sp. 2 (Fig. 4). For Hoplias sp. 3, only males were collected in 2006 and only females in March 2007, while in June and September of 2007, the frequency of occurrence was 1:1 for each sex. All sampled individuals were adults (Tab. I and Fig. 4). 

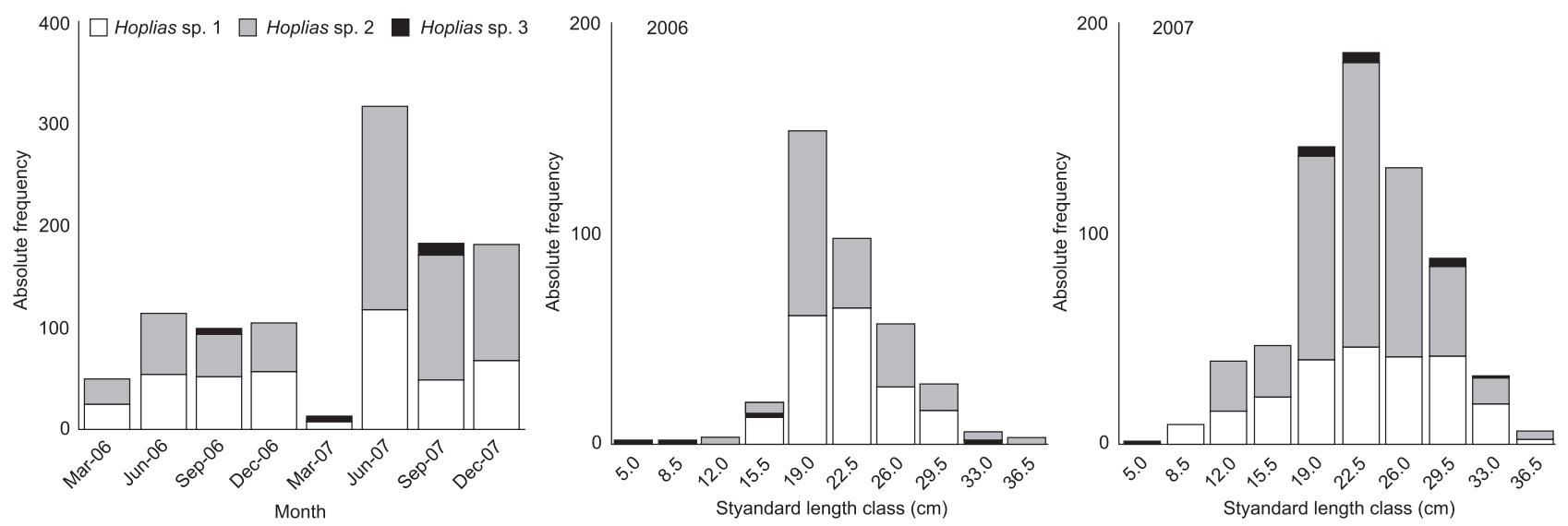

Figure 3. Absolute frequency of Hoplias sp. 1, Hoplias sp. 2 and Hoplias sp. 3 by month and by standard length class, in 2006 and 2007 , in the Upper Paraná River floodplain

Table I. Sex ratio of the species of Hoplias by year. $(\mathrm{N})$ Number of specimens, (\%) frequency percentage, $\left({ }^{*}\right)$ significant at the level of $5 \%$, $(\Delta)$ impossible to calculate $\mathrm{G}$.

\begin{tabular}{|c|c|c|c|c|c|c|c|c|c|c|}
\hline \multirow{3}{*}{ Species } & \multicolumn{5}{|c|}{2006} & \multicolumn{5}{|c|}{2007} \\
\hline & \multicolumn{2}{|c|}{ Female } & \multicolumn{2}{|c|}{ Male } & \multirow{2}{*}{ G } & \multicolumn{2}{|c|}{ Female } & \multicolumn{2}{|c|}{ Male } & \multirow{2}{*}{ G } \\
\hline & $\mathrm{N}$ & $\%$ & $\mathrm{~N}$ & $\%$ & & $\mathrm{~N}$ & $\%$ & $N$ & $\%$ & \\
\hline Hoplias sp. 1 & 101 & 53.4 & 88 & 46.6 & 0.89 & 120 & 49.0 & 125 & 51.0 & 0.10 \\
\hline Hoplias sp. 2 & 67 & 39.0 & 105 & 61.0 & $8.47^{*}$ & 213 & 49.3 & 219 & 50.7 & 0.08 \\
\hline Hoplias sp. 3 & 0 & 0 & 3 & 100.0 & $\Delta$ & 7 & 58.3 & 5 & 41.7 & 0.33 \\
\hline
\end{tabular}
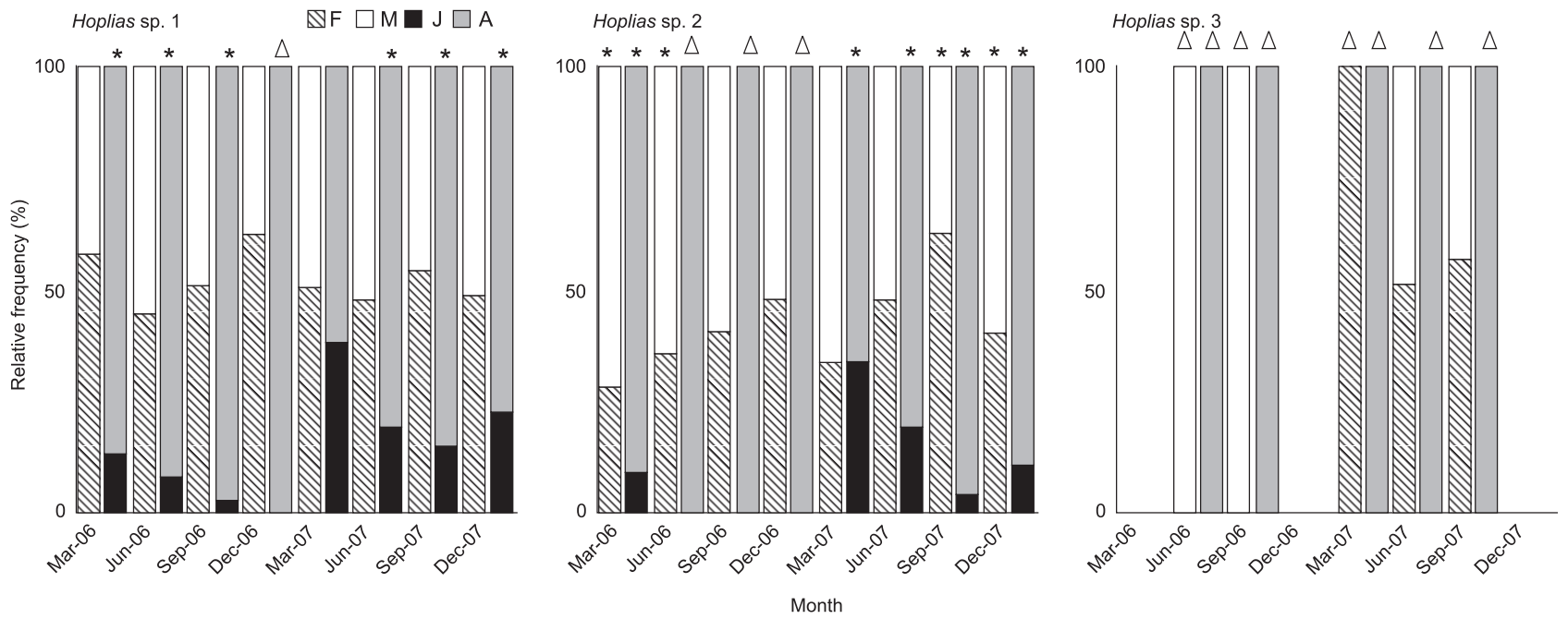

Figure 4. Quarterly variation in the relative frequencies of males (M) and females (F) and juveniles (J) and adults (A) of Hoplias sp. 1, Hoplias sp. 2 and Hoplias sp. 3 in the Upper Paraná River floodplain. ${ }^{*}$ significant at the level of 5\%; $\Delta=$ impossible to calculate G.

Considering the length class, in 2006 there was a predominance of females among the smaller $(8.5$ and $12 \mathrm{~cm})$ and larger individuals $(33 \mathrm{~cm})(\mathrm{p}<0.05)$ for Hoplias sp. 1. In 2007, there were no significant differences in sex ratio, except for the class of $26 \mathrm{~cm}$ standard length, where males prevailed ( $\mathrm{G}=$ 4.76) (Fig. 5). In contrast to Hoplias sp. 2, males still exhibited a higher occurrence in the $12,22.5,29.5$, and $36.5 \mathrm{~cm}$ size classes $(\mathrm{p}<0.05)$, with this sex being exclusive to the first and 
last classes in 2006. However, in 2007, the proportion of the sexes was almost 1:1 in most of the size classes, except among individuals larger than $36.5 \mathrm{~cm}$ standard length, in which only males occurred. We also observed only females among individuals of less than $12 \mathrm{~cm}$ standard length (Fig. 5). For Hoplias sp. 1, we recorded juveniles up to $19 \mathrm{~cm}$ in 2006 which were exclusive in the two lower standard length classes $(\mathrm{p}<0.05)$. Individuals larger than $22.5 \mathrm{~cm}$ were all adults. In 2007, there was an increase in the size of juveniles and adults, reaching 26 and $36.5 \mathrm{~cm}$, respectively (Fig. 5). For Hoplias sp. 2, we recorded only adults, with the exception of the $19 \mathrm{~cm}$ size class in 2006. However, there was an increased frequency of juveniles in 2007, observed between 8.5 and $29.5 \mathrm{~cm}$, despite the majority of adults measuring over $19 \mathrm{~cm}$ in standard length (Fig. 5). For Hoplias sp. 3, we exclusively found males in the size class ranging from 22.5 to $29.5 \mathrm{~cm}$ in 2006. In the following year, we sampled only females in the size class from 15.5 to $29.5 \mathrm{~cm}$, and only males in the $33 \mathrm{~cm}$ size class, with a sex ratio of $1: 1$ in the intermediate size classes (Fig. 5).

The equations that relate the $\mathrm{W}_{\mathrm{t}} \times \mathrm{L}_{\mathrm{s}}$ relationship for Hoplias sp. 2 were $\mathrm{W}_{\mathrm{t}}=10^{-1.80} . \mathrm{L}_{\mathrm{s}}^{3.14}$ for females and $\mathrm{W}_{\mathrm{t}}=10^{-1.67}$. $\mathrm{L}_{\mathrm{s}}^{3.03}$ for males (Fig. 6). The allometric coefficient related to the growth form of individuals and the ' $a$ ' parameter, attributed to the degree of fattening, exhibited significant differences between the sexes (ANCOVA, $\mathrm{p}<0.05$ ). The females presented a ' $b$ ' value significantly different from 3 ( $p<0.05)$, indicating positive allometric development, while the males exhibited isometric growth. For Hoplias sp. 1, the following relationships were determined: $\mathrm{W}_{\mathrm{t}}=10^{-1.79} \cdot \mathrm{L}_{\mathrm{s}}{ }^{3.06}$ for females and $\mathrm{W}_{\mathrm{t}}=10^{1.92}$. $\mathrm{L}_{\mathrm{s}}^{3.16}$ for males. However, the parameters from the length-weight

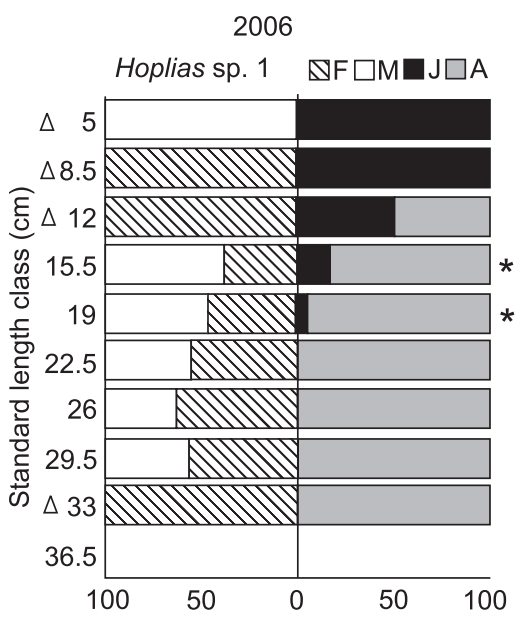

2007

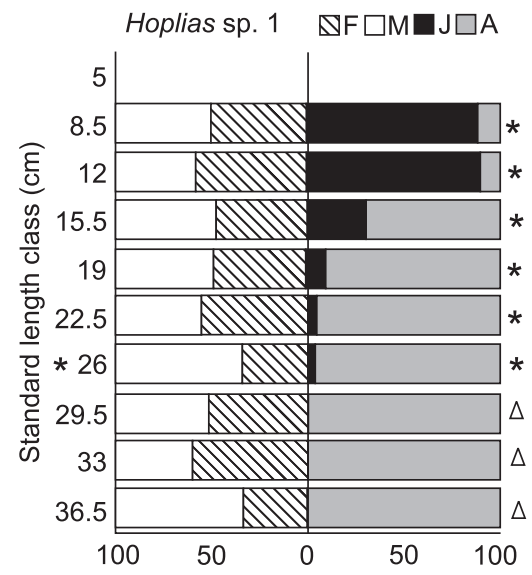

2006 Hoplias sp. 2

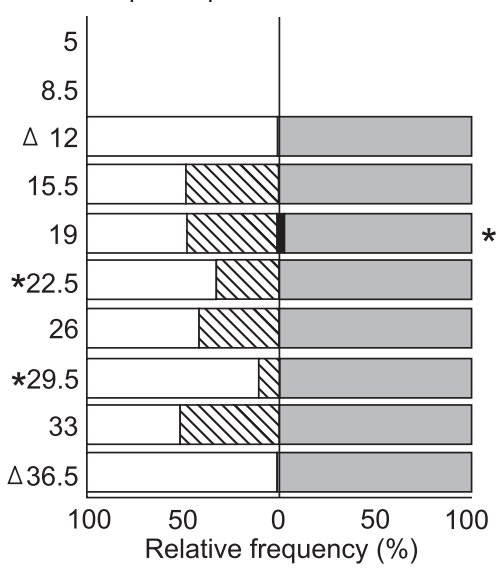

2007

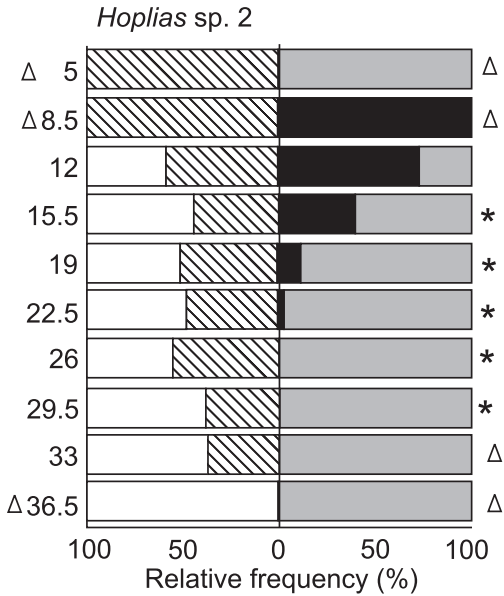

2006
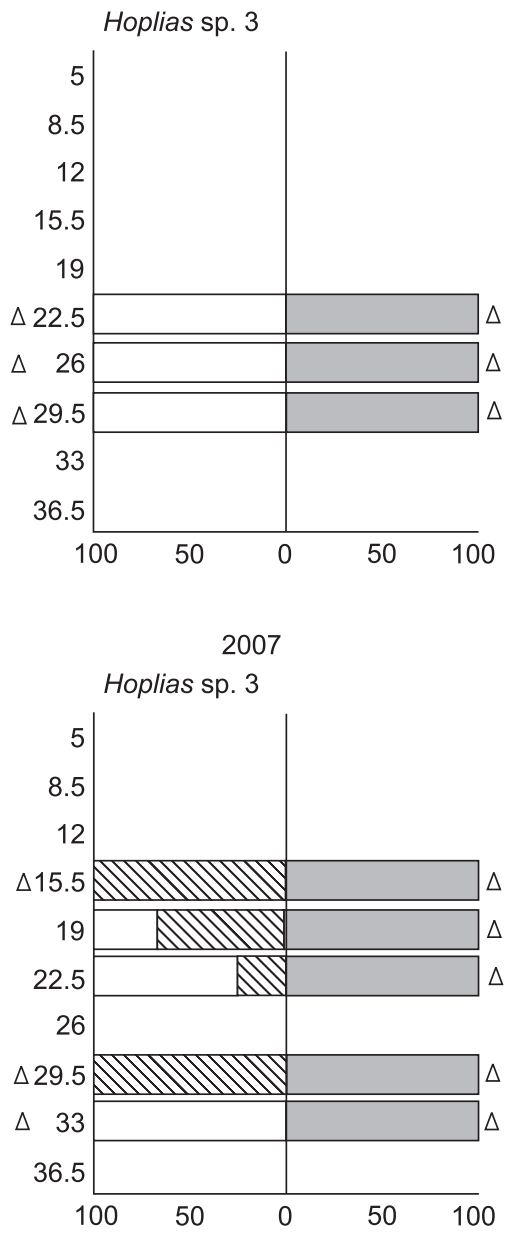

Figure 5. Relative frequency of males (M) and females (F) and juveniles (J) and adults (A) of Hoplias sp. 1, Hoplias sp. 2 and Hoplias sp. 3 for standard length class (cm) in the Upper Paraná River floodplain in 2006 and 2007. ${ }^{*}$ significant at the level of 5\%; $\Delta=$ impossible to calculate G. 
relationship ('a' and ' $b$ ') showed no significant differences between the sexes (ANCOVA, p > 0.05), exhibiting a single relationship represented by $\mathrm{W}_{\mathrm{t}}=10^{-1.86} . \mathrm{L}_{\mathrm{s}}^{3.10}$ (Fig. 6), with all individuals expressing positive allometric development, (b > $3, \mathrm{p}<0.05)$. Due to the low number of individuals of Hoplias sp. 3, we obtained only one relationship: $\mathrm{W}_{\mathrm{t}}=10^{-1.03} \cdot \mathrm{L}_{\mathrm{s}}^{2.56}$ (Fig. 6) for the pooled sexes, indicating isometric development for this species $(b=3, p>0.05)$.

\section{DISCUSSION}

In general, Hoplias sp. 1 and Hoplias sp. 2 presented the same seasonal trend of length structure regarding the abundance data, while we did not observe any pattern in Hoplias sp. 3 due to the low number of sampled individuals. So, populations of Hoplias sp. 1 and Hoplias sp. 2 were stable, as more than $80 \%$ of the first species (larger than $18 \mathrm{~cm}$ standard length) and $90 \%$ of the second species (larger than $15.3 \mathrm{~cm}$ standard length) were adult.

According to the seasonal similarity noted for Hoplias sp. 1 and Hoplias sp. 2, the higher abundance observed in June and September is probably due to higher feeding activity and preparation for breeding, factors that induce greater movement of individuals, favouring their capture (НоLzBACH et al. 2005). According to some authors (BARBIERI et al. 1982, BARBIERI 1989), the best feeding conditions for $H$. aff. malabaricus are in the period previous to and during the breeding season, which occurs between September and March in the studied floodplain. Moreover, Paiva (1974) asserts that the period between June and December shows the highest growth, when more specimens from this species complex are collected with full stomachs in the dams from north-eastern Brazil.

In contrast, the lower capture rate of individuals in March in both study years, especially in 2007, may be related to the
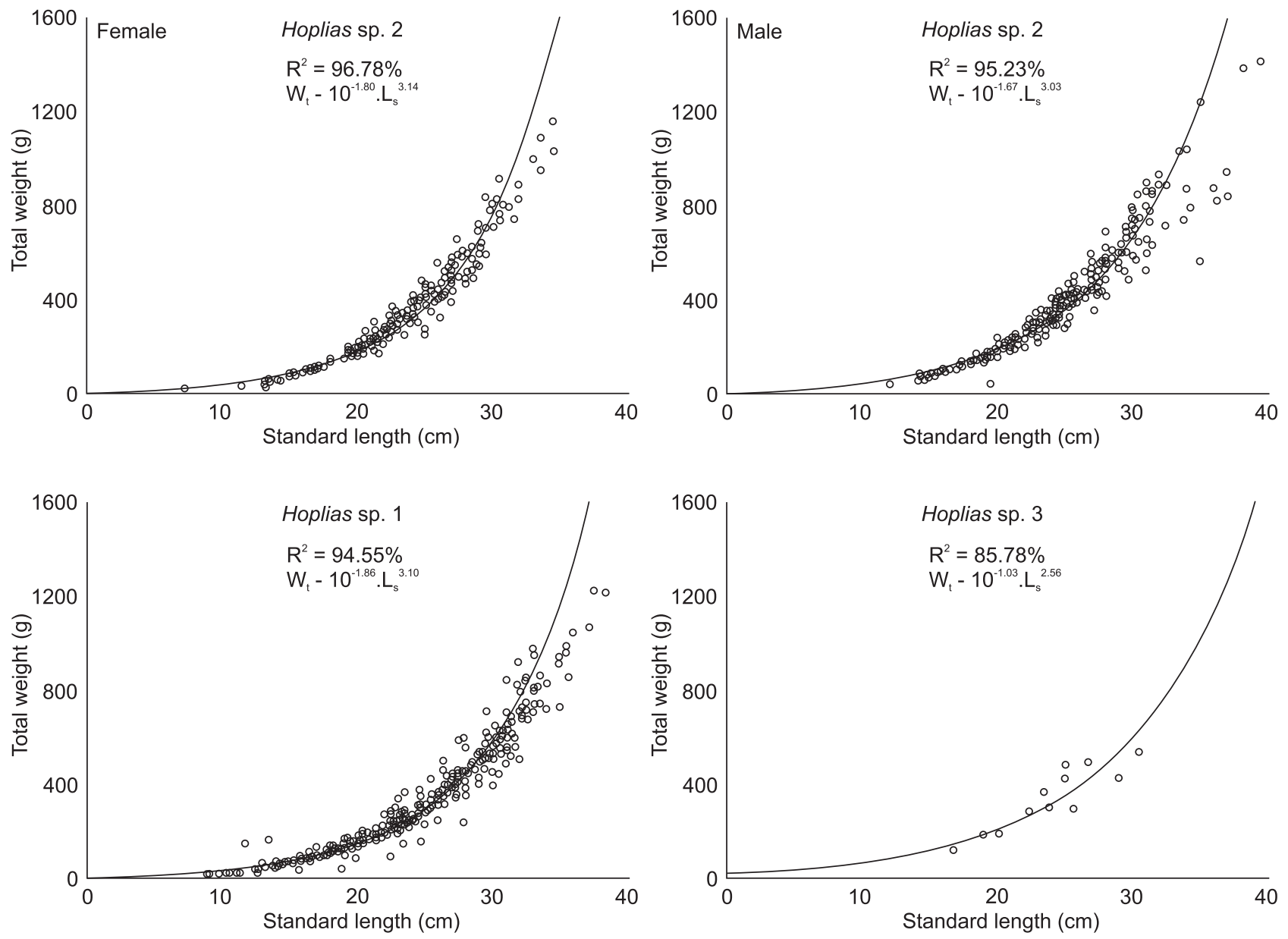

Figure 6. Total weight - standard length relationship for females alone and males alone of Hoplias sp. 2 and for the grouped sexes of Hoplias sp. 1 and Hoplias sp. 3 sampled between March of 2006 and December of 2007, in the Upper Paraná River floodplain. 
high hydrometric level in this month, a factor which promotes a habitat increase, allowing greater availability of shelter (Agostinho et al. 2004) and dispersal opportunities (Sousa \& Freitas 2008). Amadio \& Bittencourt (2005) also report the same predictions for Amazonian fish, which exhibit a wide range of responses in life history associated with the flood-drought cycle and major morphophysiological and behavioral adaptations (Zaret \& Rand 1971, Menezes \& Vazzoler 1992).

However, the slight change in absolute frequency of Hoplias sp. 1 shows the lower dependence of this species on the flood-drought cycle. Luz-AgostinHo et al. (2008) observe that $H$. aff. malabaricus is one of the species least affected by flood control in the Upper Paraná River floodplain. According to the authors, this is likely to be associated with the significant concentration of prey in years with smaller flood pulses, whereas in years with intense and prolonged floods, certain food items dominate the diet of thraira, reflecting a narrow niche. JEPSEN et al. (1999) also affirmed that these predators increase their feeding activity and development during low-water periods. Agostinho et al. (2001) verified that the capture fish with mature and semi-spent gonads in the studied floodplain are more successful in dry years for sedentary species because the large flooded area during years of prolonged floods affects the absolute density and capture of individuals which exhibit this reproductive tactic, as observed for the thraira.

In this context, the sex ratio reflects an adaptation to the food supply, with a predominance of males in dams and oligotrophic rivers, and of females when there is abundant food available (NiKOLSKY 1969, RAPOSO \& GURGEL 2001). The higher abundance of Hoplias sp. 1 females in 2006 possibly reflects the better feeding conditions in this year due to the less pronounced flood conditions. Moreover, as competition in this period was potentially stronger (LOWE-MCCONNELL 1999), it is possible that this species is a better competitor than either Hoplias sp. 2 or Hoplias sp. 3. Some authors argue specifically that aggression and foraging voracity are basic behaviours that promote the competitive superiority of exotic over native species (Holway \& Suarez 1999, Rehage \& Sih 2004, Pintor et al. 2008). Nevertheless, this last observation should be carefully considered, because confirmation of the specific competitive mechanisms must rely on preliminary feeding analyses.

Considering the seasonal similarities between Hoplias sp. 1 and Hoplias sp. 2, the remarkable increase in the native species in 2007, mainly in the number of females, may reflect a greater dependence of these species on the seasonal hydrological cycle compared to Hoplias sp. 1 (Hauser et al. in press). According to GASPAR DA Luz et al. (2001), piscivorous fish in the lakes from the Upper Paraná River floodplain seem to be favoured by flood conditions, when a greater number of juveniles reach these biotopes, and also by the gradual retraction of the water, which concentrates individuals closer together and increases their availability to predators. Studies in terrestrial (NoRRDAHL et al. 2002) and aquatic environments (MENGE
2000, Piraino et al. 2002) also demonstrate the influence of climatic and hydrological seasonality on the performance of key species.

Furthermore, according to Mazzoni \& Iglesias-Rio (2002), there is a great heterogeneity of habitats in periods with intense floods, which may intensify the proliferation of fish and aquatic invertebrates, increasing the availability of food resources for the thraira (Agostinho et al. 2004). In addition, the low oxygen levels of the water during this period, due to the incorporation of a greater biomass in the aquatic environment (Agostinho \& Júlio-Júnior 1999), may favour Hoplias sp. 2, considering the greater tolerance to water chemical variation of this species in the $H$. aff. malabaricus complex (MenNi et al. 1996).

Considering the possible impact of Hoplias sp. 1 on native species, a second hypothesis we considered was that the increase in females represents a mechanism employed by Hoplias sp. 2 and Hoplias sp. 3 that restores the population balance, as this mechanism results in a greater recruitment rate of juveniles (Nikolsky 1969, Barbieri et al. 2004). This increase occurred mainly during the reproductive period, corroborating the results of GURGEL (2004), who attributes this result to behavioral differences between the sexes as the females become more susceptible to capture in this period due to gonad weight.

In contrast, the greater proportion of males of the native species in 2006 may be related to differences in the environmental variables that favor the ability of each sex to find more suitable locations, given that variation in population parameters of fish is probably associated with the hydrological changes imposed by the seasonal regime (AвILHOA 2007). Several studies find a strong relationship between the abundance of juveniles and hydrometric level in the neotropics (Lowe-McConnel 1969, Jepsen et al. 1997, 1999). Thus, the low number of these individuals, especially in 2006, may be explained by the less pronounced flood in that year, which affects species' recruitment and increases the death rate of juveniles (Mérona \& GASCUEL 1993). Gomes \& Agostinho (1997) assert that, for most fish, flow regulation by dams caused a drastic reduction in population size due to the changes in recruitment. Another factor to be considered is that these species, in particular native species, may use other areas to complete their development (RAMOs \& KONRAD 1998/99), given the remarkable swimming ability of their larvae (PAIVA 1974).

The greater occurrence of juveniles in December and March is probably related to the intense reproduction observed in September associated with the high temperatures and feeding activity (BialetzKi et al. 2008). According to BialetzKi et al. (2002), thraira reproduce in the period prior to the flood season, which allows the larvae to reach later stages of development while most of the other trophic guilds have not yet spawned, minimizing predation and maximizing their use of available resources, with consequent improvement in offspring survival. IKEZIRI et al. (2008) observe the same strategy in several piscivorous species in the Amazon region. 
The larger standard length of males of the native species may be ascribed to their superior voracity and foraging ability relative to females of the same age classes, in addition to the low production cost of sperm (PAIVA 1974). According to GuRgeL (2004), the economy in the elaboration of sex processes explains the larger size reached by the males, since testicle development may be more related to fish growth than to the annual cycle. Dei Tos et al. (1997) verify that species exhibits paternal care from the males, they reach larger sizes, as is also observed for thraira (PRADO et al. 2006).

Regarding their length-weight relationships, both sexes of Hoplias sp. 1 ( $\mathrm{b}>3$ ) exhibited a rounded body shape, while Hoplias sp. 2 showed sex dimorphism, with robust females (b > $3)$ and isometric males $(b=3)$. Isometric growth has also been reported for Hoplias sp. 3. Divergence in these coefficients between undescribed species may supply relevant information for their future discrimination (SANTOS \& Novaes 2008). SANTOS et al. (2004) indicated that the parameters of this relationship may differ not only between species but also between stocks of the same species, considering that the growth coefficient depends on genetic, nutritional and environmental differences (Le Cren 1951, Bagenal \& Tesh 1978). Considering that the thraira were sampled in the same environments, the differences in the relationships between them probably reflect genetic dissimilarities inherent to each species.

These relationships also indicate eventual changes in body shape over ontogenetic development (COSTA \& AraúJo 2003). According to Froese (2006), if $b=3$, small specimens in the sample exhibit the same shape and condition as the adults, but if $b>3$, then the adults increase more in width than in length. Inversely, if $b<3$, then the adult fish change their body shape to be more elongated or the juveniles exhibit better nutritional condition. Therefore, adult individuals of Hoplias sp. 1, independent of sex, may experience good conditions in the Upper Paraná River floodplain, corroborating the results of HAuser et al. (in press), who verify greater factor conditions for the females of Hoplias sp. 1 compared to Hoplias sp. 2. Thus, the introduced species is welladapted in the study area, partially explaining its occupation success in the region (Prioli et al. 2004).

The higher allometric coefficient of females from Hoplias sp. 2 compared to the males may be related to their intense reproductive effort and heavier gonads. The development of the female organs occurs at a more intense rhythm than the increase in length or weight, and this is reflected in the more pronounced change in body shape throughout the lifecycle (IsAAC-NAHUM \& VAZzoler 1983). Environmental particularities that establish better or worse conditions for feeding or reproduction may also influence this coefficient (Araújo \& Vicentini 2001). Craig et al. (2005) argued that the occurrence of this sex dimorphism is expected, and the population age is a determining factor of the lengthweight relationship. According to Motra et al. (2005), morphological variation leads to functional and performance differences, resulting in divergence in resource use. Consequently, it is pos- sible that such morphometric differences between the males and females of Hoplias sp. 2 reflect differences in habitat use and niche occupation, and may affect the production of offspring.

Despite the observation that Hoplias sp. 3 exhibits isometric development, it is not possible to affirm that this species maintains the same body shape throughout its life cycle or whether any differences exist between the sexes, which, due to the low number of individuals, were analyzed together.

Our results suggest that the complex of species recognized as Hoplias aff. malabaricus present in the Upper Paraná River floodplain shows differences in some of the population attributes investigated here, especially in Hoplias sp. 1 and Hoplias sp. 2, as the number of sampled specimens allowed a more reliable evaluation. In general, the native species exhibits higher dependence on hydrological seasonality and apparently explored the available resources more efficiently during periods of conspicuous floods. Hoplias sp. 1 seems to exhibit a higher degree of population balance, given the absence of sexual dimorphism in the allometric coefficient, and little variation between males and females regarding seasonality and length structure, and both genders have a low dependence on hydrometric levels. These characteristics probably allow this species to occupy the Upper Paraná River floodplain. In this way, these differences reflect the genetic aspects of each species, reasserting the need to discriminate between the species that comprise the Hoplias aff. malabaricus complex and, especially, to denote the importance of understanding the life strategies adopted by each since they, as part of a complex, are important to the structure of the aquatic community in the study region. In addition, these species are directly related to measures of habitat management and biodiversity conservation. Consequently, further studies on the autoecology of these individuals, mainly focusing on behavioral and foraging aspects as well as the relationship between abiotic factors and their population dynamics, would be indispensable for a better understanding of how these closely-related species are able to coexist in the same environment.

\section{ACKNOWLEDGMENTS}

We wish to thank the Research Nucleus in Limnology, Ichthyology and Aquaculture (NUPELIA) and the Long-Term Ecological Research Program (LTER), both of the Universidade Estadual de Maringá, for support and logistic assistance; Itaipu Binacional for providing data on hydrological cycles of the Paraná River; and CAPES for the Master's grant to the first author and the productivity grant to the second author.

\section{LITERATURE CITED}

Aвilhoa, V. 2007. Aspectos da história natural de Astyanax scabripinnis (Teleostei, Characidae) em um riacho de floresta com araucária no sul Brasil. Revista Brasileira de Zoologia 24 (4): 997-1005. 
Agostinho, A.A. \& H.F. Júlio Junior. 1999. Peixes da bacia do alto rio Paraná, p. 374-400. In: R.H. Lowe-McConnell (Ed.). Estudos ecológicos de comunidades de peixes tropicais. São Paulo, Edusp, 535p.

Agostinho, A.A.; L.C. Gomes \& M. ZALewski. 2001. The importance of floodplains for the dynamics of fish communities of the Upper river Paraná. Ecohydrology Hydrobiology 1 (1-2): 209-217.

Agostinho, A.A.; L.C. Gomes; S. Veríssimo \& E.K. Okada. 2004. Flood regime, dam regulation and fish in the Upper Paraná river: effects on assemblage attributes, reproduction and recruitment. Fish Biology and Fisheries 14 (1): 11-19.

Agostinho, A.A.; L.C. Gomes \& F.M. Pelicice. 2007. Os Reservatórios Brasileiros e sua Ictiofauna, p. 39-106. In: A.A. AgostinHo; L.C. Gomes \& F.M. Pelicice (Eds). Ecologia e manejo de recursos pesqueiros em reservatórios do Brasil. Maringá, Eduem, 501p.

Amadio, S.A. \& M.M. Bittencourt. 2005. Táticas reprodutivas em ambientes de várzea na Amazônia, p. 65-72. In: J.F. RenNo; C. García; F. Duponchelle \& J. Nuñez (Eds). Biología de las Poblaciones de Peces de la Amazonía Y Piscicultura. Lima, IIAP-IQUITOS/IRD, 259p.

Araújo, F.G. \& R.N. Vicentini. 2001. Relação peso-comprimento da corvina Micropogonias furnieri (Desmarest) (Pisces, Sciaenidae) na Baía de Sepetiba, Rio de Janeiro. Revista Brasileira de Zoologia 18 (1): 133-138.

AVMA. 2007. Guidelines on Euthanasia. Formerly Report of the AVMA Panel on Euthanasia; 36p.

Bagenal, T.B. \& F.W. Tesch. 1978. Age and growth, p. 101-136. In: T. Bagenal (Ed.). Methods for assessment of fish production in fresh waters, third edition. Oxford, Blackwell Scientific Publications. 365p.

Barbieri, G. 1989. Dinâmica da reprodução e crescimento de Hoplias malabaricus (Bloch, 1794) (Osteichthyes, Erythrinidae) da represa do Monjolinho, São Carlos/SP. Revista Brasileira de Zoologia 6 (2): 225-233.

Barbieri, G.; J.R. Verani \& M.C. Barbieri. 1982. Dinâmica quantitativa da nutrição de Hoplias malabaricus (Bloch, 1794) na represa do Lobo (Brotas-Itirapina/SP), (Pisces, Erythrinidae). Revista Brasileira de Biologia 42 (2): 295-302.

Barbieri, G.; F.A. Salles; M.A. Cestarolli \& A.R. Teixeira-Filho. 2004. Estratégias reprodutivas do dourado, Salminus maxillosus e do curimbatá, Prochilodus lineatus no rio Mogi Guaçu, estado de São Paulo, com ênfase nos parâmetros matemáticos da dinâmica populacional. Acta Scientiarum: Biological Sciencies 26 (2): 169-174.

Begon, M.; C.R. Townsend \& J.L. Harper, 2007. Ecologia: De indivíduos a Ecossistemas. Porto Alegre, Artmed, $4^{\text {th }}$ ed., 752p.

Bertollo, L.A.C.; G.G. Born; J.A. Dergam; A.S. Fenocchio \& O. Moreira-Filho. 2000. A biodiversity approach in the neotropical Erythrinidae fish, Hoplias malabaricus. Karyotypic survey, geographic distribution of cytotypes and cytotaxonomic consideration. Chromosome Research 8 (7): 603-613.
Bialetzki, A.; K. Nakatani; P.V. Sanches \& G. Baumgartner. 2002. Spatial and temporal distribution of larvae and juveniles of Hoplias malabaricus (Characiformes, Erythrinidae) in the Upper Paraná river floodplain, Brazil. Brazilian Journal of Biology 62 (2): 211-222.

Bialetzki, A.; K. Nakatani; P.V. Sanches; G. Baumgartner; M.C. Makrakis \& T.L. Taguti. 2008. Desenvolvimento inicial Hoplias aff. malabaricus (Bloch, 1794) (Osteichthyes, Erythrinidae) da planície alagável do Alto rio Paraná, Brasil. Acta Scientiarum Biological Sciences 30 (2): 141-149.

Costa, M.C. \& F.G. Araújo. 2003. Lenght-weight relationship and condition factor of Micropogonias furnieri (Desmarest) (Perciformes, Sciaenidae) in the Sepetiba Bay, Rio de Janeiro State, Brazil. Revista Brasileira de Zoologia 20 (4): 685690.

Craig, J.M.; M.V. Thomas \& S.J. Nichols. 2005. Length-weight relationship and a relative condition factor equation for lake sturgeon (Acipenser fulvescens) from the St. Clair River system (Michigan, USA). Journal of Applied Ichthyology 21 (2): 81-85.

Cunico, A.M.; W.J. Graça; S. Veríssimo \& L.M. Bini. 2002. Influência do nível hidrológico sobre a assembléia de peixes em lago sazonalmente isolada da planície de inundação do alto rio Paraná. Acta Scientiarum Biological Sciences 24 (2): 383-389.

Dei Tos, C.; A.A. Agostinho \& H.I. Suzuki. 1997. Population structure and reproductive biology of Loricarichthys platymetopon (Siluriformes, Pisces) in the Upper river Paraná. Brazilian Archives of Biology and Technology 40 (4): 793 807.

Dergam, J.C. \& L.A.C. Bertollo. 1990. Karyotypic diversification in Hoplias malabaricus (Ostheichthyes, Erythrinidae) of São Francisco and Alto Paraná Basins. Brazilian Journal of Genetics 13 (4): 755-766.

Dergam, J.A.; H.I. Suzuki; O.A. Shibatta; L.F. Duboc; H.F. Júlio Jr; L. Giuliano-Caetano \& W.C. Black IV. 1998. Molecular biogeography of the neotropical fish Hoplias malabaricus (Erythrinidae: Characiformes) in the Iguaçu, Tibagi, and Paraná rivers. Genetics and Molecular Biology 21 (4): 493496.

Froese, R. 2006. Cube law, condition factor, and weight-length relationships: history, meta-analysis and recommendations. Journal of Applied Ichthyology 22 (4): 241-253.

Gaspar da Luz, K.D.; F. Abujanra; A.A. Agostinho \& L.C. Gomes. 2001. Caracterização trófica da ictiofauna de três lagoas da planície aluvial do Alto rio Paraná, Brasil. Acta Scientiarum Biological Sciences 23 (2): 401-407.

GÉrY, J. 1977. Characoids of the World. Neptune City, T.F.H. Publications, 672p.

Goldberg, D.E. \& S.M. Scheiner. 1993. ANOVA and ANCOVA: Field Competition Experiments, p. 69-93. In: S.M. SCHEINER \& J. Gurevitch (Eds). Design and Analysis of Ecological Experiments. New York, Chapman \& Hall, 445p. 
Gomes, L.C. \& A.A. Agostinho. 1997. Influence of the flooding regime on the nutritional state and juvenile recruitment of the curimba, Prochilodus scrofa, Steindachner, in Upper Paraná river, Brazil. Fisheries Management and Ecology 4 (4): 263-274.

Gomes, B.V.C.; R.S. Scarpelli; F.P. Arantes; Y. Sato; N. Bazzoli \& E. Rizzo. 2007. Comparative oocyte morphology and early development in three species of trahiras from the São Francisco River basin, Brazil. Journal of Fish Biology 70 (5): 1412-1429.

Graça, W.J. \& C.S. Pavanelli. 2007. Peixes da planície inundação do Alto rio Paraná e áreas Adjacentes. Maringá, Eduem, 241p.

Gurgel, H.C.B. 2004. Estrutura populacional e época de reprodução de Astyanax fasciatus (Cuvier) (Characidae, Tetragonopterinae do rio Ceará Mirim, Poço Branco, Rio Grande do Norte, Brasil. Revista Brasileira de Zoologia 21 (1): 131-135.

Holzbach, A.J.; G. Baumgartner; F. Bergmann; L.B. Rezende Neto; D. Baumgartner; P. Sanches \& E.A. Gubiani. 2005. Caracterização Populacional de Steindachnerina insculpta (FernándezYépez, 1948) (Characiformes, Curimatidae) no Rio Piquiri. Acta Scientiarum, Biological Sciences, 27 (4): 347-353.

Holway, D.A. \& A.V. Suarez. 1999. Animal Behavour: an essential component of invasion biology. Trends in Ecology and Evolution 14 (8): 328-330.

IKeZIrI, A.A.S.L.; L.J. QueIroz; C.R.C. Doria; L.F. FÁVARO; T.R. ARAújo \& G. Torrente-Vilara. 2008. Estrutura populacional e abundância do Apapá-Amarelo, Pellona castelnaeana (Valenciennes, 1847) (Clupeiformes, Pristigasteridae), na Reserva Extrativista do Rio Cautário, Rondônia. Revista Brasileira de Zoociências 10 (1): 41-50.

Isaac-Nahum, V.J. \& A.E.A.M. Vazzoler. 1983. Biologia reprodutiva de Micropogonias furnieri (Desmarest, 1923) (Teleostei, Scienidae). 1. Fator de condição como indicador do período de desova. Boletim do Instituto Oceanográfico 32 (1): 63-69.

Jepsen, D.B.; K.O. Winemiller \& D.C. Taphorn. 1997. Temporal patterns of resource partitioning among Cichla species in a Venezuelan blackwater river. Journal of Fish Biology $\mathbf{5 1}$ (6): 1085-1108.

Jepsen, D.B.; K.O. Winemiller; D.C. Taphorn \& D. Rodriguez Olarte. 1999. Age structure and growth of peacock cichlids from rivers and reservoirs of Venezuela. Journal of Fish Biology 55 (2): 433-450.

Júlio Júnior, H.F.; C. Dei Tós; A.A. Agostinho \& C.S. Pavanelli. 2009. A massive invasion of fish species after eliminating a natural barrier in the Upper rio Paraná basin. Neotropical Ichthyology 7 (4): 709-718.

Le Cren, E.D. 1951. The length-weight relationship and seasonal cycle in gonad weight in condition in the perch (Perca fluvuatilis). The Journal of Animal Ecology 20 (2): 201-219.

Lowe-McConnel, R.H. 1969. Cichlid fishes of Guiana, South America, with notes on their ecology and breeding behavior. Zoological Journal of the Linnean Society 48 (2): 255-302.
Lowe-McConnell, R.H. 1999. Respostas dos peixes às condições em águas tropicais, p. 243-275. In: R.H. Lowe-MCCONNELL (Ed.). Estudos ecológicos de comunidades de peixes tropicais. São Paulo, Edusp, 535p.

Luiz, E.A.; K.D.G. Luz; R.S. Costa; J.D. LatinI; H.F. JÚLIO-JÚNIOR \& L.C. Gomes. 2004. Structure of the fish assemblage in biotopes and subsystems o the Upper Paraná river floodplain, p. 117123. In: A.A. Agostinho; L. Rodrigues; L.C. Gomes; S.M. Thomaz $\&$ L.E. Miranda (Eds). Structure and functioning of the Parana river and its floodplain LTER - SITE 6 (PELD sítio 6). Maringá, Eduem, 275p.

Luz-Agostinho, K.D.G.; A.A. Agostinho; L.C. Gomes \& H.F. JúlioJR. 2008. Inûuence of ûood pulses on diet composition and trophic relationships among piscivorous ûsh in the Upper Parana River ûoodplain. Hydrobiologia 607 (1): 187-198.

Mazzoni, R. \& R. Iglesias-Rios. 2002. Distribution pattern of two fish species in a coastal stream in southeast Brazil. Brazilian Journal of Biology 62 (1): 171-178.

Mello, F.T.; C. Iglesias; A.I. Borthagaray; N. Mazzeo; J. Vilches; D. LARREA \& R. BALlabio. 2006. Ontogenetic allometric coefûcient changes: implications of diet shift and morphometric traits in Hoplias malabaricus (Bloch) (Characiforme, Erythrinidae). Journal of Fish Biology 69 (6): 1770-1778.

Menezes, N.A. \& A.E.A.M. VAzzoler. 1992. Síntese de conhecimento sobre o comportamento reprodutivo dos Characiformes da América do Sul (Teleostei, Ostariophysi). Revista Brasileira de Biologia 52 (4): 627-640.

Menge, B.A. 2000. Top-down and bottom-up community regulation in marine rocky intertidal habitats. Journal of Experimental Marine Biology and Ecology 250 (1): 257-289.

Menni, R.C.; S.E. Gómez \& F.L. Armengol. 1996. Subtle relationships: freshwater fishes and water chemistry in southern south America. Hydrobiologia 328 (3): 173-197.

Mérona, B. \& D. Gascuel. 1993. The effects of flood regime and fishing effort on the overall abundance of an exploited fish community in the Amazon floodplain. Aquatics Living Resources 6 (2): 97-108.

Motta, C.M.; S. Tammaro; P. Simoniello; M. Prisco; L. Ricchiari; P. AndReuCCetTI \& S. Filosa. 2005. Characterization of cortical alveoli in several species of Antarctic notothenioids. Journal of Fish Biology 66 (2): 442-453.

Nikolsky, G.V. 1969. Theory of fish population dynamics. Edinburgh, Oliver \& Boyd, 323p.

NorRdahl, K.; T. Klemola; E. KorpimÄKI \& M. KoIvula. 2002. Strong seasonality may attenuate trophic cascades: vertebrate predator exclusion in boreal grassland. Oikos 99 (3): 419-430.

Odum, E.P. 1988. Ecologia. Rio de Janeiro, Guanabara, 434p.

Orsi, M.L.; E.D. Carvalho \& F. Foresti. 2004. Biologia populacional de Atyanax altiparanae Garutti \& Britiski (Teleostei, Characidae) do Médio Rio Paranapanema, Paraná, Brasil. Revista Brasileira de Zoologia 21 (2): 207-218.

PAIVA, M.P. 1974. Crescimento, alimentação e reprodução de traíra, Hoplias malabaricus (Bloch), no nordeste brasi- 
leiro. Fortaleza, Imprensa Universidade Federal do Ceará, 32p.

PAZZA, R. \& H.F. Júlio JúnIOR. 2003. Occurrence of three sympatric cytotypes of Hoplias malabaricus (Pisces, Erythrinidae) in the Upper Paraná River Foodplain (Brazil). Cytologia 68 (2): 159-163.

Petry, A.C.; A.A. Agostinho \& L.C. Gomes. 2003. Fish assemblages of tropical floodplain lagoons: exploring the role of connectivity in a dry year. Neotropical Ichthyology 1 (2): 111-119.

Petry, A.C; A.A. Agostinho; P.A. Piana \& L.C. Gomes. 2007. Effects of temperature on prey consumption and growth in mass of juvenile trahira Hoplias aff. Malabaricus (Bloch, 1794). Journal of Fish Biology 70 (6): 1855-1864

PINTOR, L.M.; A. SiH \& M.L. Bauer. 2008. Differences in aggression, activity and boldness between native and introduced populations of an invasive crayûsh. Oikos 117 (11): 1629-1636.

Piraino, S.; G. Fanelli \& F. Boero. 2002. Variability of species' roles in marine communities: change of paradigms for conservation priorities. Marine Biology 140 (5): 1067-1074.

Poff, N. L.; J.D. Allan; M.B. Bain; J.R. KarR; K.L. Prestegaard; B.D. Richter; R.E. Sparks \& J.C. Stromberg. 1997. The natural flow regime. BioScience 47 (11): 769-784.

Prado, C.P.A.; L.M. Gomiero \& O. Froehlich. 2006. Spawning and parental care in Hoplias malabaricus (Teleostei, Characiformes, Erythrinidae) in the Southern Pantanal, Brazil. Brazilian Journal Biology 66 (2B): 697-702.

Prioli, A.J.; L.C. Lucio; T.C. Maniglia; S.M.A.P. Prioli; H.F. Júlio Júnior; R. Pazza; H. Carrer \& L.M. Prioli. 2004. Molecular markers and genetic variability of Hoplias aff. malabaricus populations from the Upper Paraná river floodplain, p. 169174. In: A.A. Agostinho; L. Rodrigues; L.C. Gomes; S.M. Thomaz \& L.E. Miranda (Eds). Structure and functioning of the Parana river and its floodplain LTER - SITE 6 (PELD sítio 6). Maringá, Eduem, 275p.

Ramos, L.A. \& H.G. Konrad. 1998/99. Biologia reprodutiva de Hemiancistrus sp. (Osteichthyes, Loricariidae) do Rio dos Sinos, RS. Boletim do Instituto de Pesca 25: 45-50.

RAPOSO, R.M.G. \& H.C.B. GuRgeL. 2001. Estrutura populacional de Serrasalmus spilopleura Kner, 1860 (Pisces, Serrasalmidae) da lagoa de Extremoz, Estado do Rio Grande do Norte, Brasil. Acta Scientiarum Biological Sciences 23 (2): 409-414.

Rehage, J.S. \& A. Sin. 2004. Dispersal behavior, boldness and the link to invasiveness: A comparison of our Gambusia species. Biological Invasions 6 (3): 379-391.

Santos, A.C.A. \& J.L.C. Novaes. 2008. Population Structure of two Astyanax Baird \& Girard, 1854 (Teleostei, Characidae) species from Upper Paraguaçu River. Brazilian Archives of Biology and Technology 51 (1): 105-112.

Santos, A.L.B; A.L.M. Pessanha; M.M. Costa \& F.G. Araújo. 2004. Relação peso-comprimento de Orthopristis ruber (Cuvier) (Teleostei, Haemulidae) na Baia de Sepetiba, Rio de Janeiro,Brazil. Revista Brasileira de Zoologia 21 (2): 185-187.
SousA, R.G.C. \& C.E.C. Freitas. 2008. The influence of flood pulse on fish communities of floodplain canals in the Middle Solimões River, Brazil. Neotropical Ichthyology 6 (2): 249-255.

Souza Filho, E.E. \& J.C. Stevaux. 2004. Geology and geomorphology of the Baía-Curutuba-Ivinheima river complex, p. 1-29. In: S.M. Thomaz; A.A. Agostinho \& N.S. Hahn, (Eds). The Upper Paraná river and its floodplain (physical aspects, ecology and conservation). Leiden, Backhuys Publishers, 393p.

Souza, J.E.; E.N. Fragoso-Moura; N.F. Verani; O. Rocha \& J.R. VERANI. 2008. Population structure and reproductive biology of Cichla kelberi (Perciformes, Cichlidae) in Lobo Reservoir, Brazil. Neotropical Ichthyology 6 (2): 201-210.

StatSoft. 1996. Statistics for Windows. Tulsa, Version 7.1, StatSoft [electronic manual index].

Thomaz, S.M.; T.A. Pagioro; L.M. Bini; M.C. Roberto \& R.R.A. RoCHA. 2004. Limnological characterization of the aquatic environments and the influence of hydrometric levels, p. 75102. In: S.M. Thomaz; A.A. Agostinho \& N.S. Hahn (Eds). The Upper Paraná River and its floodplain: physical aspects, ecology and conservation. Leiden, Backhuys Publishers, 393p.

VAnzolini, P.E. 1993. Métodos estatísticos elementares em sistemática zoológica. São Paulo, Hucitec, 130p.

VAzzolER, A.E.A.M. 1996. Biologia da reprodução de peixes teleósteos: teoria e prática. Maringá, Eduem, 169p.

Vazzoler, A.E.A.M. \& S.A. Amadio. 1990. Aspectos biológicos de peixes Amazônicos. XIII. Estrutura e comportamento de cardumes multiespecíf1cos de Semaprochilodus (Characiformes, Prochilodontidae) no Baixo rio Negro, Amazonas, Brasil. Revista Brasileira de Biologia 50 (3): 537-546.

Vicari, M.R.; R.F. ARtoni \& L.A.C. Bertollo. 2005. Comparative cytogenetics of Hoplias malabaricus (Comparative cytogenetics of Hoplias malabaricus (Pisces, Erythrinidae): A population analysis in adjacent hydrographic basins. Genetics and Molecular Biology 28 (1): 103-110.

Vicari, M.R.; R. Pazza; R.F. Artoni; V.P. Margarido \& L.A.C. Bertollo. 2006. Cytogenetics and Biogeography: Considerations about the Natural Origin of Hoplias malabaricus (Characiformes, Erythrinidae) on the Iguaçu River. Brazilian Archives of Biology and Technology 49 (2): 297-303.

VIEIRA,S. 1991. Introdução à Bioestatística. Rio de Janeiro, Editora Campus, 203p.

Winemiller, K.O. 1989. Ontogenetic diet shifts and resource partitioning among piscivorous fishes in the Venezuelan ilanos. Environmental Biology of Fishes 26 (3): 177-199.

ZAR, J. H. 1996. Biostatistical analysis. London, Prentice Hall, 662p.

ZARET, T.M. \& A.S. RAND. 1971. Competition in tropical stream fishes: support for the competitive exclusion principle. Ecology 52 (2): 336-342.

Submitted: 07.III.2011; Accepted: 16.XI.2011. Editorial responsibility: Wolmar B. Wosiacki 